Pregledni znanstveni rad DOI: $10.17234 /$ Croatica.42.4 UDK: 821.163.42.09-05Pranjković, I. Primljen: 30. XI. 2017. Prihvaćen: 23. I. 2018.

\title{
- IVO PRANJKOVIĆ
KAO POVJESNIČAR KNJIŽEVNOSTI
}

\author{
Iva Beljan Kovačić \\ Filozofski fakultet Sveučilišta u Mostaru \\ Odjel za hrvatski jezik i književnost \\ iva.beljan12@gmail.com
}

Rad polazi od teze da dio znanstvenih istraživanja Ive Pranjkovića prelazi lingvističke okvire i zahvaća problematiku povijesti književnosti. To je najviše izraženo u dijelu njegova opusa koji se bavi književnošću franjevačke provincije Bosne Srebrene, u starim granicama koje su obuhvaćale bosanski i hercegovački, ali i dalmatinski i slavonsko-ugarski prostor. U tim se tekstovima autor susreće s problemima književnopovijesnog opisa, kontekstualizacije i vrednovanja građe. Ovaj se rad usmjerava na književnopovijesne probleme kojima se Pranjković bavio, na rješenja koja je ponudio te njihovu korist $\mathrm{u}$ novim istraživanjima ovog dijela hrvatske književnosti.

Ključne riječi: Ivo Pranjković, književnost franjevaca Bosne Srebrene, povijest hrvatske književnosti

1.

S obzirom na to da se lingvistika i znanost o književnosti sve više specijaliziraju te se između njih stvaraju dosta čvrste granice, može se činiti neobičnim proučavanje doprinosa jezikoslovca književnopovijesnim istraživanjima. Međutim kad je riječ o znanstvenom opusu Ive Pranjkovića, to se proučavanje pokazuje opravdanim i poticajnim. 
U literaturi o Pranjkoviću, napose u prikazima njegove knjige Jezik $i$ beletristika, već je isticano da on "prevladava metodološke isključivosti u istraživanju lingvističkih i književnih sustava", odnosno da "nastoji svrsishodno povezati lingvistiku i književnost" (Meić 2010b: 169). Zamijećeno je također da radovi iz ove knjige, premda autor na više mjesta definira svoj pristup kao lingvistički, "pružaju građu za daljnje stilističke i/ili književnokritičke interpretacije" (Katnić-Bakaršić i Požgaj Hadži 2010: 88) te da "Pranjković zaslužuje da govorimo o njemu (i) kao stilističaru koji je trajno inspiriran intrigantnim odnosom između jezika i književne umjetnine" (isto: 90).

U napisima o knjigama Hrvatski jezik i franjevci Bosne Srebrene (2000) te Franjevačko spisateljstvo na hrvatskome jeziku (2008) također je konstatirano da Pranjković široko zasniva svoje radove. Stjepan Damjanović primjećuje da bi se o odabranim temama "moglo pisati isključivo jezikoslovno, ali autor se odlučio za drukčiji pristup. Jezikoslovna sastavnica temeljna je i u ovim raspravama, ali su one odreda obogaćene sadržajima filološke i kulturološke naravi" (Damjanović 2000: 367). I drugi recenzenti zamjećuju da Pranjković promišlja "o jezikoslovnim, filološkim, ali i književnim i općenito kulturološkim zaslugama" obrađenih pisaca (Brlobaš 2009: 467) te da "nudi i niz podataka koji se tiču i političkih, i društvenih, i kulturnih zbivanja” (Mićanović 2000: 196).

Ovaj se rad stoga usmjerava upravo na književnopovijesni aspekt Pranjkovićevih istraživanja s namjerom da se detaljnije analizira ono što je zamijećeno u kritici te da se o Pranjkoviću progovori (i) kao o povjesničaru književnosti. Područje istraživanja u kojem je ovaj aspekt osobito došao do izražaja i kojem se Pranjković stalno vraćao dio je starije hrvatske književnosti nastao u nekadašnjim okvirima franjevačke provincije Bosne Srebrene, koji su obuhvaćali bosanski, hercegovački, dalmatinski i slavonsko-ugarski prostor. Toj je problematici posvetio više desetaka bibliografskih jedinica: niz različitih članaka, dvije autorske i dvije priređene knjige kao i nekoliko urednički potpisanih zbornika radova. Tomu treba dodati mentorstva diplomskih i doktorskih radova koji istražuju ovu problematiku, kao i kolegij Jezik $i$ kultura bosanskih franjevaca na studiju kroatistike Filozofskoga fakulteta u Zagrebu.

Osnovni je Pranjkovićev interes u ovim radovima jezična problematika, u prvom redu uloga književnosti na prostoru provincije Bosne Srebrene u procesima standardizacije hrvatskoga jezika. Međutim radovi prelaze jezikoslovne okvire te se pokazuju kao važan doprinos književnopovijesnim istraživanjima i poticaj povjesničarima književnosti. 
Njegov doprinos proučavanju povijesti hrvatske književnosti istražit ću analizirajući najprije antologiju Hrvatska književnost Bosne i Hercegovine od XIV. do sredine XVIII. stoljeća (2005). Zatim se koncentriram na brojne radove koji se u prvom redu usmjeravaju na jezična pitanja, ali zalaze i u književnopovijesne probleme te (izravno i neizravno) nude smjernice za njihovo rješavanje.

Kad obrađuje teme iz književnosti Bosne Srebrene, Ivo Pranjković često teži sintetskim tipovima radova, dobrim dijelom zbog činjenice da takvih sinteza o odabranim piscima ima vrlo malo. U tom se procesu susreće s temeljnim problemima koji stoje pred povjesničarem književnosti, a to su prema modelu metodološkoformacijske analize književnopovijesnih radova koji je osmislila Perina Meić - problemi izbora pisaca (i reprezentativnih tekstova u antologijama), periodizacije, književnopovijesne interpretacije, recepcije i vrednovanja (usp. Meić 2010a: 51-72). Primjenjujući taj model analize, usmjeravam se na nabrojene probleme, kao i na rješenja koja Pranjković nudi.

2.

U ediciji Hrvatska književnost Bosne i Hercegovine u 100 knjiga Matice hrvatske u Sarajevu 2005. godine izašla je knjiga Hrvatska književnost Bosne i Hercegovine od XIV. do sredine XVIII. stoljeća, koju je priredio Ivo Pranjković. Knjiga donosi izbor iz tekstova dvadeset i pet pisaca ovoga vremena, opsežnu uvodnu studiju, iscrpan rječnik, bibliografiju te opis načela priređivanja. Premda zamišljena kao antologija s izborom tekstova i osnovnim podacima o autorima, ona se dotiče i nekih važnih književnopovijesnih pitanja.

Prvo je pitanje izbor pisaca. Pranjković pokazuje načelo poštivanja kulturnoga konteksta nekadašnje Bosne Srebrene. Ta je provincija, uslijed ekspanzije Osmanskoga Carstva, obuhvaćala širok prostor, tako da se u drugoj polovici 16. i početkom 17. st. prostirala na "većem dijelu Dalmacije, u Slavoniji, u Srijemu, u Bačkoj, Banatu i južnoj Mađarskoj, u okolici Beograda te u dijelovima Rumunjske i Bugarske" (Pranjković 2005b: 6). Budući da se nakon Bečkoga rata našla na teritoriju triju država - osmanske, habsburške i mletačke - sredinom 18. st. se dijeli zbog teškoća u funkcioniranju provincija: dalmatinski dio odvojio se 1735, a prekosavski 1757 . godine. Bosansko-hercegovački dio zadržao je status matice s povijesnim imenom, 
a u 19. se stoljeću u posebnu provinciju odijelila i Hercegovina (1852. kao kustodija, a 1892. podignuta je na rang provincije).

Bosna Srebrena jedinstven je kulturni prostor na kojem se razvila vrlo živa književna i kulturna djelatnost. Nakon njezinih dioba u 18. i 19. st. književna produkcija u svim dijelovima nastavlja zajedničku književnu tradiciju, što se vidi iz žanrovskoga sustava, poimanja funkcije književnosti, tematskih, oblikovnih i stilskih značajki. ${ }^{1}$

Premda naslov antologije ograničava korpus na granice današnje Bosne i Hercegovine, Pranjković u svoj izbor uključuje i pisce iz nekadašnjeg dalmatinskog i slavonsko-ugarskog dijela Bosne Srebrene, svjestan da je njihovo književno stvaranje nezaobilazno za razumijevanje predstavljene književnosti, primjerice za razumijevanje poetičkih osobitosti, recepcije, utjecaja i sl. Sličan kriterij Pranjković uspostavlja i kad je riječ o piscima iz 14. stoljeća koji su iz inozemstva dolazili u Bosnu i Hercegovinu, kao i u slučaju Jurja Dragišića, rođenog u Srebrenici, koji je život proveo izvan domovine. Svoj izbor Pranjković i objašnjava:

Svi predstavljeni pisci vezani su za djelovanje Bosne Srebrene, ali svi nisu i rođeni u Bosni i Hercegovini. Neki su od njih rođeni Talijani (kao Bartol Alvernski ili Jakov Markijski), a neki su rođeni sjeverno od Save ili čak u Mađarskoj (Blaž Zalčanin, Mihovil Radnić, Ivan Stražemanac, Lovro Bračuljević, Stjepan Vilov i Luka Čilić). Oni dakle u strožem smislu riječi ne bi pripadali književnosti Bosne i Hercegovine, ali kako njihova djela predstavljaju vrlo važan i neodvojiv dio spisateljske djelatnosti franjevaca Bosne Srebrene, prirodno je da budu uvršteni (i) u ovu ediciju (Pranjković 2005b: 11).

Slična načela primjenjuje i u drugim svojim radovima, što se dobro vidi u koncepciji knjige Franjevačko spisateljstvo na hrvatskome jeziku, u koju uključuje autore sa svih dijelova nekadašnje Bosne Srebrene, te naznačuje neke korisne smjernice $u$ istraživanju veza i razlika među njima.

Treba napomenuti da Pranjković u predstavljanju hrvatske književnosti u Bosni i Hercegovini slijedi i dugu tradiciju njezina znanstvenog proučavanja od F. Lastrića u 18. stoljeću, preko I. F. Jukića, J. Matkovića, M. V. Batinića u 19, do J. Jelenića i drugih istraživača u 20. st. Povjesničar književnosti Boris Ćorić napominje da je takva praksa u starijim razdobljima postojala i u historiografiji drugih odijeljenih provincija nekadašnje Bosne Srebrene (Ćorić 1979: 22-23). U svim se ovim (najčešće biobibliografskim)

O osobinama primjerice književnoga rada u odcijepljenoj Hercegovini, koji nastavlja zajedničku tradiciju, v. Beljan 2014: 143-177, 242-279. 
djelima primjenjuju ista načela izbora pisaca koja uvažavaju specifičnosti kulturnoga prostora Bosne Srebrene, bez kojih je književnopovijesna prezentacija ovoga korpusa manjkava a njezino razumijevanje nepotpuno (usp. Beljan 2014: 7-9).

Hrvatska književnost Bosne i Hercegovine od XIV. do sredine XVIII. stoljeća obuhvaća pisce rođene "u vremenskom rasponu od gotovo četiri stoljeća, od Bartola Alvernskoga, rođenog oko 1333. pa do fra Luke Čilića, rođenoga 1707. godine, a njihova djela nastajala su i/ili bila objavljivana između 1373. (kad je pisana Dubia Bartola Alvernskoga) i osamdesetih godina 18. stoljeća" (Pranjković 2005b: 11). U obradi ove građe Pranjković se ne dotiče posebno pitanja periodizacije, dijelom i zbog zacrtane raspodjele građe u samoj ediciji.

U izboru tekstova priređivač poštuje načelo estetske relevantnosti bira u tom smislu vrednije odlomke, često narativne. Međutim poštuje i načelo reprezentativnosti, što znači da ne bira samo narativne odlomke jer se tako može steći pogrešan dojam o autoru ili djelu (što se često događa na osnovi hrestomatija). Njegov odabir tekstova znatno je proširen u odnosu na onaj u Bosanskohercegovačkoj književnoj hrestomatiji (usp. Kuna i dr. 1974: 139-217), na koju su se često oslanjali dosadašnji izbori. Priređivanje tekstova i načela koja Pranjković primjenjuje u izdanjima za širu publiku predstavljaju ogledan primjer posla i dobre smjernice za slične radove, pogotovo s obzirom na to da u izdanjima ove građe u $\mathrm{BiH}$ u novije vrijeme ne nalazimo uvijek istu dosljednost.

Osim u izboru pisaca i tekstova, s nekim se važnim književnopovijesnim problemima, kao što su primjerice kontekstualizacija i vrednovanje, Pranjković susreće i pišući uvodnu studiju. Ona je koncipirana kao kratak nacrt povijesti ove književnosti u naznačenom vremenu, strukturiran po modelu "tradicionalne pozitivističke književnopovijesne podvrste" (Meić 2010a: 84-86).

Prvi dio studije tako opisuje političke, društvene i crkvene okolnosti u kojima ova produkcija nastaje, zatim specifičan književni i kulturni kontekst Bosne Srebrene. Posebna se pozornost posvećuje jezičnom uzusu spisatelja i njegovim obilježjima. Središnji dio studije čini katalog autora iz čijih se djela donosi izbor. Za svakog se donose biobibliografski podaci, počesto komentiraju ili korigiraju postojeći (usp. Pranjković 2005b: 35). Prezentiraju se potom podaci o izvorima, izdanjima, opisuju se žanrovski, sadržajni i strukturni aspekti djela, grafijske i jezične osobine, a donose se i kratke informacije o recepciji (isto: 17, 28-29,38) te vrednovanje unutar opisanog književnog sustava (isto: $24,34,36,43,44$ ). 
S književnopovijesnim se problemima Pranjković susreće i u drugim svojim radovima. Većina ih je okupljena u knjigama Hrvatski jezik i franjevci Bosne Srebrene, Franjevačko spisateljstvo na hrvatskome jeziku i Jezik i beletristi$k a$, a dobar ih je broj osim toga u različitim zbornicima i časopisima.

Karakter većine radova iz ovog segmenta Pranjkovićeve bibliografije (izuzevši uglavnom lingvostilistički zasnovane radove iz Jezika i beletristike) ima sintetska obilježja: prigode za koje su članci nastali, kao i činjenica da se najčešće pišu o relativno nepoznatim, neobrađenim djelima ili opusima, motiviraju autora da se ne usmjerava na uži jezikoslovni problem, nego da ponudi širu sliku odabrane teme.

Neki od tih radova zato su koncipirani kao široki pregledi književnosti Bosne Srebrene ili kao sinteze o pojedinim autorima. ${ }^{2}$ U njima Pranjković redovno opisuje povijesni kontekst i osobitosti ove kulture, navodi reprezentativne autore i djela te nudi žanrovske klasifikacije ove književnosti, čija je jedna od specifičnosti u vremenu prije 20. st. upravo žanrovski sustav i poimanje funkcije književnosti. ${ }^{3}$

I radovi o pojedinačnim piscima ili rukopisima slično su koncipirani. Započinju biobibliografskim podacima, pri čemu Pranjković često ukazuje na nerazriješena mjesta u biobibliografiji, komentira podatke iz postojeće literature ili predlaže rješenja, a ako je riječ o rukopisu, predlaže moguće autore i dataciju. U svim radovima ukratko opisuje povijesni i književnopovijesni kontekst. Zatim prelazi na kratku analizu žanrovskih, sadržajnih, kompozicijskih i drugih aspekata djela, na izvore, utjecaje, prevodilački/

2 Primjerice Franjevci Bosne Srebrene i hrvatski jezik (Pranjković 2008a: 9-27), Hrvatski jezik u Bosni i Hercegovini (Pranjković 2015: 11-29), već spomenuti predgovor antologiji Hrvatska književnost Bosne i Hercegovine od XIV. do sredine XVIII. stoljeća, zatim Fra Frano Jukić i hrvatski jezik: skica za portret Ivana Frane Jukića (Pranjković 2000: 150-179), predgovor Izabranim djelima I. F. Jukića (Pranjković 2001: 5-14) i drugi. U literaturi je primjerice zamijećeno da studija o Jukiću predstavlja "pravi nacrt za suvremenu monografiju o toj iznimnoj osobnosti franjevačke povijesti na našim prostorima" (Damjanović 2000: 369).

3 Tako primjerice klasificira djela ove književnosti na nabožna djela, povijesne spise, pjesnička djela, putopise, memoarska djela, priručnike za osnovno obrazovanje, jezikoslovne spise, liječništvo (Pranjković 2008a: 12-15) ili na drugom mjestu na vjerske pouke, propovijedi, teološke i filozofske spise, lirske i epske pjesme, pripovijesti i romane, memoare ili tzv. zapamćenja, ljetopise, povijesne i zemljopisne spise, političke i druge proglase, naputke za poljodjelstvo, bukvare, likaruše itd. (Pranjković 2000: 7). 
kompilatorski postupak i njegove implikacije i drugo. Slijedi analiza jezičnih i stilskih osobitosti određenog djela ili opusa kao središnji problem rada.

Zahvaljujući takvoj koncepciji radovi prelaze okvire lingvističkih i nude smjernice proučavateljima književnosti. Osim izravnih podataka koje pružaju, povjesničaru književnosti još važnije mogu biti analogije koje se u brojnim slučajevima daju uspostaviti između jezične i književnopovijesne razine pa ću se tim mogućnostima ovdje pozabaviti.

Analizirajući jezične osobine na svim razinama - grafija, pravopis, fonologija, morfologija, sintaksa, red riječi, leksik - Pranjković teži sintezama: nastojeći opisati osobitosti odabranog djela ili autora, ide i prema opisu elemenata koji jezik i stil određenog autora vežu s prethodnicima i suvremenicima, sa žanrovski istovrsnim djelima istog doba, te s cjelinom spisateljstva određenog razdoblja. Zahvaljujući tome u radovima se uspostavljaju i neke važne književnopovijesne koordinate. Razrađuju se sličnosti i razlike između jezika i stila (ali i žanrovskih, strukturnih i drugih elemenata) u djelima autora iz istog i iz različitih razdoblja. ${ }^{4}$

Tako se primjerice u radovima o M. Divkoviću, P. Papiću, S. Matijeviću (Pranjković 2008a: 28-52) naznačuju poetičke osobitosti pisaca 17. stoljeća. Zapažanja o jezičnim slojevima i utjecajima (lokalnom, zatim utjecaju dalmatinsko-dubrovačke književnosti, utjecaju latinske i talijanske lektire i obrazovanja pisaca) također su važna za istraživanja književnosti ovog razdoblja. Pranjkovićeve analize upozoravaju zatim na sličnosti, ali i neke značajne razlike između jezika i stila pisaca 17 . i prve polovice 18 . i pisaca druge polovice 18 . stoljeća. Najbolji je primjer analiza razlika između Lašvaninova i Benićeva jezika i stila (usp. Pranjković 2000: 23-79). ${ }^{5}$

4 Ovaj je aspekt Pranjkovićevih radova, uspostavljanje "guste mreže raznorodnih odnosa" (Mićanović 2000: 196), često istican u kritičkim osvrtima na njegove knjige. Stjepan Damjanović primjećuje da Pranjkovićev pristup prelazi jezikoslovni i kombinira se s filološkim: "Filologičnost se ove knjige očituje i čestom korištenju usporedbe kao metode: uspoređuje se grafija koju upotrebljava Dobretić s Kašićevom i Relkovićevom, jezik fra Nikole Marčinkušića Lašvanina uspoređuje se sustavno s jezikom fra Bone Benića, a jezična rješenja koja su oni odabirali omjeravaju se o ona koja nalazimo u Ljetopisu krě̌evskoga samostana ili u tekstovima fra Jake Baltića. Gramatička terminologija fra Stjepana Marijanovića uspoređuje se s Relkovićevom, fra Šitovićevom i suvremenom hrvatskom. Usporedbom se otkrivaju utjecaji (npr. Kranjčevićeve i Harambašićeve poezije na pjesništvo fra Joze Markušića). Pranjković uspoređuje istovremene i raznovremene činjenice te tako plete mrežu u koju 'hvata' činjenice, tj. one dobivaju koordinate koje čitatelju olakšavaju njihove važnosti i njihove naravi” (Damjanović 2000: 368).

5 Na potrebu zamjećivanja razlika između ovih pisaca upozorava u svojim radovima već Boris Ćorić (usp. Ćorić 1979: 25-27), a u novije se vrijeme taj problem aktualizira (usp. Beljan 2014: 45-61). 
U radovima pak o piscima 19. stoljeća - V. Viciću, G. Martiću, I. F. Jukiću, J. Baltiću, A. Kneževiću i drugim - zamjećuju se veze s prethodnim razdobljima, ali i značajne razlike koje se u odnosu na ranija stoljeća pojavljuju u poetici pisaca ovoga preporodnog doba. Jezična i stilska analiza i u ovim primjerima donosi neke vrijedne književnopovijesne rezultate. Polazeći primjerice od jezične analize jednog dijela Martićevih Osvetnika, Pranjković dolazi do njegove kontekstualizacije i valorizacije unutar književne tradicije iz koje je potekao (Pranjković 2000: 180-195). U kontekstu Jukićeva književnoga rada osobito izdvaja putopise kao tipičan žanr romantizma (isto: 155). Baveći se A. Kneževićem izdvaja one njegove jezične i stilske osobitosti koje ga čine dobrim pripovjedačem. Analizu temelji na primjeru "dvaju literarno najambicioznijih, pa možda i najuspjelijih njegovih djela, a to su Krvava knjiga [...] i napisi u četvrtom broju Bosanskog prijatelja" (isto: 197), pokazujući svijest o tome da je u proučavanju ove građe literarnost nužno protegnuti na nefikcionalne tekstove.

Radove o piscima 20. stoljeća Pranjković koncipira ponešto uže nego o (manje obrađenim) starijim piscima, a često izrijekom napominje da se analiza usmjerava tek na neke formalnojezične postupke, ili da, kao u slučaju Šimićevih Preobraženja, "nema drugih pretenzija nego da nam to prebogato pjesništvo još jedanput približi otkrivajući u njemu ponešto što je u dosadašnjim čitanjima možda ostalo nezapaženo" (Pranjković 2003: 62). Međutim već je primijećeno da se ovi radovi ne pokazuju važnima samo za najuže shvaćenu lingvistiku, nego i za izučavanje književnosti (usp. Meić 2010b: 171). Lingvostilističke analize Šimićeva i Pešordina pjesništva (Pranjković 2003: 43-62; 113-127), Andrićevih tzv. fratarskih pripovijesti, koje nam ponešto kazuju i o vezi Andrićeva stvaralaštva sa starijom hrvatskom književnosti u BiH (isto: 169-177), zatim članci o Šimićevim (isto: 27-41) i Andrićevim razmišljanjima o jeziku (Pranjković 2005a: 175-183) te o književnopovijesnim obilježjima Markušićeva pjesništva, napose o Kranjčevićevu utjecaju na formiranje njegova pjesničkog jezika (Pranjković 1982: 178-184), donose vrijednih spoznaja o poetikama hrvatske književnosti u 20. st.

Dakle gotovo svaki Pranjkovićev rad nudi i književnopovijesnu kontekstualizaciju obrađenog djela i pisca, što je jedan od osnovnih zadataka povijesti književnosti. Kad je riječ o piscima Bosne Srebrene, Pranjković vrlo često i vrednuje opisane pojave, i to ne samo na jezičnoj nego i na široj razini. ${ }^{6}$ Progovara i o recepciji ovih pisaca, što izravno, što neizravno:

6 V. primjerice radove o M. Dobretiću (Pranjković 2000: 21), I. F. Jukiću (isto: 155), B. Beniću (isto: 66) itd. 
neizravno o njoj progovara opisujući jezične osobitosti, često napominjući da su ovi spisatelji gradili jezični uzus ne udaljujući se previše od materinskog idioma, upravo zato što su imali na umu komunikaciju s ciljanom - vrlo širokom - publikom. Primjećuje da su zbog toga "u standardizacijskim procesima, posebice onima koji su bili vezani za puk i njegovo (jezično) prosvjećivanje, odigrali važniju ulogu negoli npr. estetski neusporediva i neprocjenjivo vrijedna književnost starog Dubrovnika" (Pranjković 2000: 7).

Analogija koja se može uspostaviti između Pranjkovićevih zaključaka o jezičnom uzusu i o recepciji ove književnosti, samo je jedna od mnogih koje ova istraživanja omogućuju povjesničaru književnosti. Kao dobar primjer plodotvornosti uspostavljanja analogija između Pranjkovićevih jezičnih istraživanja i istraživanja književnopovijesnih problema neka posluže radovi o franjevačkim ljetopisima 18. i 19. stoljeća. Analizirajući razlike između jezika i stila dvojice ljetopisaca iz 18. stoljeća - Nikole Lašvanina i Bone Benića - čiji su ljetopisi naizgled vrlo slični sadržajno i formalno, Pranjković dolazi do poticajnih rezultata. Uspoređujući donekle sličan jezik dvojice ljetopisaca, zaključuje da su "u dosta specifičnosti, naročito stilskih, izrazito različiti, čak suprotstavljeni. [...] Benićev je stil poprilično razbarušen i osoban, a Lašvaninov više služben i neutralan. Benić ima bujnu maštu pa događajima o kojima govori koješta i pridodaje, barem u načinu prezentacije, a Lašvanin je uglavnom objektivni izvještač o događajima" (Pranjković 2000: 23). Za Lašvaninov jezik Pranjković konstatira da je u odnosu na Benićev odmjereniji, sa znatno manje orijentalizama, talijanizama i latinizama kojima obiluje Benićev tekst. ${ }^{7}$

Naratološka analiza dvaju ljetopisa kod drugih istraživača dolazi do sličnih rezultata. Lašvaninov je stil pripovijedanja u odnosu na Benićev poprilično suzdržan. Drži se historiografske distancirane konvencije pripovijedanja, ne istupa kao akter u priči, ne komentira događaje (usp. Beljan 2011: 158-166). S druge strane Benićev je način pripovijedanja daleko od povjesničarskih konvencija: osobniji je, s autorom/pripovjedačem kao akterom, često glavnim akterom i uvijek komentatorom povijesnih događaja. Benić pripovijeda vrlo plastično i živo, stvarajući pripovjedni tekst koji ne mari za disciplinu i odmjerenost historiografskoga pisma (usp. Beljan 2011: 166-193).

\footnotetext{
Lašvaninov je jezik “odmjeren, discipliniran i, rekao bih, već u velikoj mjeri standardiziran”, on "svjesno nastoji oko jezične čistoće, pa izbjegava porabu prevelikog broja orijentalizama, talijanizama i latinizama, a i one koje upotrebljava nastoji što više prilagoditi i fonološkom, i grafijskom, i morfološkom, i tvorbenom ustrojstvu hrvatskoga jezika" (Pranjković 2000: 46).
} 
Pranjkovićeva analiza leksika, u kojoj se pokazalo da Lašvanin nastoji oko jezične čistoće dok Benićev tekst neobično obiluje orijentalizmima, također je korisno polazište za narativnu analizu. Benićev pripovjedač, koji postaje središnji akter ljetopisa, angažiran u administrativnim, političkim, ekonomskim i gospodarskim pitanjima, zahtijeva preuzimanje rječnika one društvene skupine koja je u tim životnim područjima dominantna. Pranjković primjećuje, što je znakovito, da su u Benića osobito česti orijentalizmi koji znače vršitelja radnje muškog roda (usp. Pranjković 2000: 60). Njegov stil pripovijedanja, koji teži plastičnosti, živosti i ne mari za historiografske konvencije, traži i leksik aktivan u svakodnevnoj konverzaciji onog doba, dok Lašvanin nastoji koristiti knjiški, "službeniji” leksik.

U radu o kreševskom ljetopisu i njegovim autorima, u segmentu o Marijanu Bogdanoviću, Pranjković također otvara nekoliko poticajnih tema. Analizirajući nekoliko (rijetkih) odlomaka Bogdanovićeva ljetopisa koji su pisani hrvatskom jezikom, zamjećuje da se njegov jezik opet donekle razlikuje od Benićeva, a razlike su se pokazale i u narativnoj analizi (usp. Beljan 2011: 196-216).

Pranjkovićeva jezično-stilska analiza Baltićeva Godišnjaka, najvrednijeg ljetopisa iz 19. stoljeća, pokazuje izrazite sličnosti s prethodnicima iz 18. stoljeća (Pranjković 2000: 114). S druge pak strane Pranjković zamjećuje i razlike (isto: 80), posebnosti Baltićeva strukturiranja zapisa (isto: 83 ) te osobito njegovu sklonost generalizacijama i frazeologiziranim konstrukcijama kao važno obilježje njegova stila (isto: 112). Radovi povjesničara književnosti pokazuju da je upravo to jedan od elemenata koji Baltićevo pripovijedanje izrazito približavaju književnoumjetničkom (usp. Beljan 2014: 232-233).

Ocjene o literarnoj uspješnosti (Pranjković 2000: 47, 114), zapažanje i izdvajanje onih primjera koji rječito govore o stilu i stilotvornosti te o pripovjedačkom umijeću ljetopisaca, prelaze okvire lingvističkoga bavljenja ljetopisima te potiču na proučavanje ljetopisa kao vrijednih književnih, a ne samo historiografskih djela. Primjer s ljetopisima pokazuje i to da Pranjković teži komparativnim analizama, da čvrsto povezuje svoje radove, kontekstualizira pisce i pojave, nudeći pritom dobre smjernice za književnopovijesne analize.

Ova povezanost njegovih radova s književnopovijesnim istraživanjima nalazi svoje očitovanje i u radovima o znanstvenicima: Rastku Drljiću, Ignaciju Gavranu i Tugomiru Alaupoviću. Pranjković analizira djela ovih autora izdvajajući njihove prednosti i nedostatke te uklopljenost u znanstvene uzuse 
svoga vremena. Upozorava na važnost Drljićeve doktorske disertacije o Martinu Nediću koja:

pripada najboljim i najtemeljitije pisanim prilozima proučavanju bogate književne i uopće kulturne ostavštine franjevaca Bosne Srebrene koji su nastali u krilu iste te redodržave, a što se tiče proučavanja života i djela samoga fra Martina Nedića i začetaka ilirizma u Bosni, ta je disertacija do danas, tj. i nakon punih šezdeset godina od njezina objavljivanja, ostala nezaobilazna (Pranjković 2000: 241).

Analizirajući rad Ignacija Gavrana na priređivanju franjevačkih ljetopisa - načela koja je primijenio, akribičnost i pouzdanost rezultata - Pranjković napominje da "zaslužuje posebnu pozornost cijele hrvatske kulturne javnosti" te da je "vrijedan divljenja" (isto: 243). Obrađujući pak Alaupovićevu monografiju o I. F. Jukiću, skreće pozornost na jedno od najvažnijih djela u počecima moderne književnopovijesne misli u BiH te ukazuje na neke od lucidnih Alaupovićevih zaključaka koji su se održali sve do danas (Pranjković 2008a: 141-147).

4.

Kad je riječ o proučavanju književnosti Bosne Srebrene i njezinu dosadašnjem statusu u povijesti hrvatske književnosti, mogla bi se primijeniti Pranjkovićeva rečenica o njezinoj istraženosti s jezičnog aspekta. U predgovoru svoje knjige Hrvatski jezik i franjevci Bosne Srebrene on piše:

Nadam se da će ovdje sabrani tekstovi, između ostaloga, biti još jedna potvrda onoga što je, doduše, među stručnjacima odavno poznato, ali nije ni do danas na odgovarajući način osviješteno ni vrednovano, a to je činjenica da je književna, znanstvena, popularnojezikoslovna i uopće kulturna djelatnost franjevaca Bosne Srebrene presudno važna za povijest hrvatskoga jezika, posebice za njegovu standardizaciju utemeljenu na (novo)štokavskome narječju (Pranjković 2000: 6).

Ova je književnost, premda postoji konsenzus o njezinoj vrijednosti, $\mathrm{i}$ danas relativno neproučena i neopisana. Razlog je dijelom njezina specifičnost - uglavnom je to nefikcionalna književnost praktične namjene - zbog čega je često vrednovana kao kulturnopovijesna, a ne kao književna činjenica. Primjerenost dosadašnje prezentacije ove književnosti u novije se vrijeme propituje. ${ }^{8}$ Jedan od razloga zbog kojih istraživanja Ive Pranjkovića mogu

8 Usp. Grmača 2012; Beljan 2014: 5-62; Meić 2015: 11-37. 
biti poticajna (i) povjesničaru književnosti, upravo je njegovo sagledavanje Bosne Srebrene kao živog kulturnog prostora s književnošću koju odlikuje raznovrsnost oblika i funkcija, komunikativnost i primjerenost prilikama u kojima nastaje. ${ }^{9}$

Književnost nekadašnje provincije Bosne Srebrene Pranjković promatra kao jednu cjelinu. Takav kontekst proučavanja nude osobito antologija Hrvatska književnost Bosne i Hercegovine od XIV. do sredine XVIII. stoljeća, zatim knjiga Franjevačko spisateljstvo na hrvatskome jeziku, kao i neki radovi sintetske naravi, među kojima se izdvajaju Hrvatski jezik u Bosni $i$ Hercegovini (Pranjković 2015: 11-29) te Jezično stanje u BiH tijekom 18. stoljeća (Pranjković 2008b: 163-168). Kao što je već napomenuto, ovakvim pristupom autor analizirane pojave predstavlja u širokom okviru, omogućujući lakše shvaćanje poetičkih veza između pisaca s različitih dijelova provincije te recepcije njihovih djela.

Osim toga Pranjković donosi i ideju o kulturnim krugovima u Bosni Srebrenoj, vrlo interesantnu (i) za povijest književnosti. Analizirajući u brojnim svojim radovima jezik i stil autora s bosansko-hercegovačkog, slavonsko-ugarskog i dalmatinskog dijela Bosne Srebrene, dolazi do zaključaka o sličnostima, ali i nekim razlikama, koje mu služe kao polazište za ideju o spisateljskim krugovima u nekadašnjoj Bosni Srebrenoj. Prepoznaje tri kruga: bosanski, slavonski i dalmatinski. Od distinktivnih obilježja najviše se bavi razlikama u grafiji, tj. činjenicom da su pripadnici slavonskog/budimskog kruga uređivali latiničnu grafiju prema mađarskim, a u druga dva kruga prema talijanskim uzorima.

U Pranjkovićevu se tako modelu istraživanja susreću različiti književni sustavi i podsustavi: od zavičajnog kulturnog mikroprostora (važnog za analizu jezičnog uzusa obrađenih pisaca), preko regionalnog do prostora Bosne Srebrene kao cjeline. Proučavanje ovih sustava vodi računa o njihovim povezanostima, a uzima u obzir i društveno-politički kontekst u kojem su nastajali, primjerice osmanski politički kontekst u proučavanju pisaca s prostora Bosne i Hercegovine.

9 Za jezik te književnosti Pranjković na više mjesta konstatira da je "već u prvoj polovici 18. stoljeća bio u velikoj mjeri standardiziran, ujednačen, a donekle i polifunkcionalan, tj. pripravljen za raznolike tipove pismene i usmene komunikacije" (Pranjković 2000: 46). 


\section{5.}

Znanstvena istraživanja Ive Pranjkovića prelaze lingvističke okvire i zalaze u problematiku povijesti književnosti. To je najviše izraženo u dijelu njegova opusa koji se bavi starijom hrvatskom književnosti u nekadašnjim okvirima franjevačke provincije Bosne Srebrene, koji su obuhvaćali današnji bosanski, hercegovački, dalmatinski i slavonski prostor. U tim se tekstovima - različitim člancima, autorskim knjigama, kao i u poslu oko priređivanja građe autor susreće s problemima izbora pisaca, književnopovijesne interpretacije, vrednovanja, recepcije. Rješenja koja je Pranjković ponudio pokazuju se vrlo poticajnima za nova istraživanja ove književnosti.

S problemom izbora pisaca Pranjković se susreće u antologiji Hrvatska književnost Bosne i Hercegovine od XIV. do sredine XVIII. stoljeća. U izboru u obzir uzima jedinstvenost kulturnog prostora nekadašnje Bosne Srebrene. Pisce s prostora $\mathrm{BiH}$ tako proučava u širokom kontekstu, omogućavajući lakše uočavanje povezanosti, poetičkih osobitosti i osobito recepcije. Povjesničarima književnosti vrlo poticajan može biti i njegov nacrt regionalnih kulturnih krugova u Bosni Srebrenoj.

Problemu književnopovijesne interpretacije Pranjković dijelom pristupa izravno, a dijelom preko jezične problematike. U tom kontekstu pokazuje osjetljivost za nijanse - za potrebu uvođenja distinkcija i zamjećivanja poetičkih razlika u književnosti koja se često sagledava kao monolitna cjelina.

Pitanju vrednovanja Pranjković pristupa tako što opisane pojave rangira unutar predstavljene književne tradicije, vodeći računa o njihovoj svrsishodnosti, funkcionalnosti, uspjehu koji su postigle u publici, kao i o estetskim dometima, imajući pritom na umu njihove specifičnosti (povezanost estetskog i pragmatičnog aspekta).

Povjesničarima književnosti ovi su radovi vrijedni i zbog toga što se u književnopovijesnim istraživanjima mogu analoški primijeniti Pranjkovićeva zapažanja o jezičnoj problematici. Zbog svega toga, premda sâm autor nije na to pretendirao, Pranjkovićevi radovi predstavljaju vrijedan doprinos proučavanju povijesti hrvatske književnosti, koji novim istraživačima nudi korisne smjernice. 


\section{LITERATURA}

Beljan, Iva. 2011. Pripovijedanje povijesti: ljetopisi bosanskih franjevaca iz 18. stoljeća. Zagreb - Sarajevo: Synopsis.

Beljan, Iva. 2014. Na rubu književnosti: rasprave o hrvatskim piscima u BiH. Zagreb - Sarajevo: Synopsis.

Brlobaš, Željka. 2009. O franjevcima, stvarateljima i čuvarima hrvatskoga jezičnog izričaja. "Rasprave Instituta za hrvatski jezik i jezikoslovlje", 35/1, 461-467.

Ćorić, Boris. 1979. Književnopovijesne odlike djela Kultura i bosanski franjevci Julijana Jelenića. Godišnjak instituta za jezik i književnost u Sarajevu: Odjeljenje za književnost, VIII, 9-35.

Damjanović, Stjepan. 2000. Malo drukčiji Pranjković. "Kolo”, 3, 367-369.

Grmača, Dolores. 2012. Spisateljstvo franjevaca Bosne Srebrene u književnoj historiografiji. "Bosna franciscana", 36, 35-50.

Katnić-Bakaršić, Marina i Vesna Požgaj Hadži. 2010. Zapis o Ivi Pranjkoviću kao stilističaru. Jezična skladanja: Zbornik o šezdesetogodišnjici prof. dr. Ive Pranjkovića [ur. Lada Badurina i Vine Mihaljevićc. Zagreb: Udruga đaka Franjevačke klasične gimnazije - Visoko u Zagrebu.

Kuna, Herta i dr. 1974. Bosanskohercegovačka književna hrestomatija I: Starija književnost. Sarajevo: Zavod za izdavanje udžbenika.

Meić, Perina. 2010a. Čitanje povijesti književnosti: metodološki modeli književnopovijesnih istraživanja u hrvatskoj znanosti o književnosti. Mostar: Alfa.

Meić, Perina. 2010b. Od riječi do riječi: književnokritičke zabilješke. Zagreb - Sarajevo: Synopsis.

Meić, Perina. 2015. Izazovi: hrvatska književnost u BiH i druge teme. Zagreb - Sarajevo: Synopsis.

Mićanović, Krešimir. 2000. Što prošlost znači onima koji žive sadašnjost. "Motrišta", 18, 191-197.

Pranjković, Ivo. 1982. Pjesništvo Josipa Markušića (stilske i jezične osobitosti). Fra Josip Markušić: Zbornik radova sa simpozija u povodu 100. obljetnice rođenja [ur. Josip Turčinović]. Zagreb: Kršćanska sadašnjost - Sarajevo: Revija "Nova et vetera", 178-184.

Pranjković, Ivo. 2000. Hrvatski jezik i franjevci Bosne Srebrene. Zagreb: Matica hrvatska.

Pranjković, Ivo. 2001. Ivan fra Frano Jukić (1818-1857). Ivan Frano Jukić. Izabrana djela [prir. Ivo Pranković]. Zagreb: Konzor, 5-14.

Pranjković, Ivo. 2003. Jezik i beletristika. Zagreb: Disput.

Pranjković, Ivo. 2005a. Andrićevi susreti s riječima. Bosna franciscana, 23, 175-183.

Pranjković, Ivo. 2005b. Predgovor. Hrvatska književnost Bosne i Hercegovine od XIV. do sredine XVIII. stoljeća [prir. Ivo Pranjković]. Sarajevo: Matica hrvatska; HKD Napredak, 5-45.

Pranjković, Ivo. 2008a. Franjevačko spisateljstvo na hrvatskome jeziku. Zagreb: Hrvatska sveučilišna naklada. 
Pranjković, Ivo. 2008b. Jezično stanje u BiH tijekom 18. stoljeća. Zbornik o Marku Dobretiću [ur. Marko Karamatić]. Sarajevo - Dobretići: Kulturno-povijesni institut Bosne Srebrene, 163-168.

Pranjković, Ivo. 2015. Hrvatski jezik u Bosni i Hercegovini. Jezik Hrvata u Bosni i Hercegovini od Matije Divkovića do danas [ur. Jadranka Gvozdanović, Pavao Knezović i Marinko Šišak]. Zagreb: Sveučilište u Zagrebu - Hrvatski studiji, 11-29.

\section{SUMMARY}

\section{IVO PRANJKOVIĆ AS A HISTORIAN OF LITERATURE}

The paper is based on the thesis that a part of Ivo Pranjković's scholarly research transcends the linguistic framework and addresses the issues of the history of literature. This is most evident in the part of Pranjković's opus dealing with the literature of the Franciscan Province of Bosna Srebrena, in the old frontiers which encompassed Bosnia and Herzegovinian, as well as the Dalmatian and Slavonian-Hungarian areas. In these texts, Pranjković addresses the problems of literary-historical interpretation, contextualization, and validation of literary works. This paper focuses on the literary-historical problems Pranjković has dealt with, the solutions he offered and their contribution to the new research in this field of Croatian literature.

Key words: Ivo Pranjković, the literature of the Bosna Srebrena Franciscans, the history of Croatian literature. 